University for Business and Technology in Kosovo

UBT Knowledge Center

UBT International Conference

2017 UBT International Conference

Oct 28th, 2:00 PM - 3:30 PM

\title{
E-Commerce Implementation in Kosovo
}

\author{
Besnik Skenderi \\ University for Business and Technology, besnik.skenderi@ubt-uni.net \\ Diamanta Skenderi \\ University for Business and Technology
}

Follow this and additional works at: https://knowledgecenter.ubt-uni.net/conference

Part of the Databases and Information Systems Commons, and the Information Security Commons

\section{Recommended Citation}

Skenderi, Besnik and Skenderi, Diamanta, "E-Commerce Implementation in Kosovo" (2017). UBT International Conference. 192.

https://knowledgecenter.ubt-uni.net/conference/2017/all-events/192

This Event is brought to you for free and open access by the Publication and Journals at UBT Knowledge Center. It has been accepted for inclusion in UBT International Conference by an authorized administrator of UBT Knowledge Center. For more information, please contact knowledge.center@ubt-uni.net. 


\title{
E-Commerce Implementation in Kosovo
}

\author{
Besnik Skenderi ${ }^{1}$, Diamanta Skenderi ${ }^{1}$ \\ UBT - Higher Education Institution, Prishtina, Kosovo \\ besnik.skenderi@ubt-uni.net
}

\begin{abstract}
In this paper, author had analyzed journal articles that were published by Alemayehu \& Heeks, (2007) and Hwang, Jung, \& Selvendy (2006). Both articles are about e-commerce and in first article (Alemayehu \& Heeks, 2007) authors had analyzed impact of cultural differences, telecomunication infrastructure and local market. In addition, authors of this research paper were focused on consumers that are purchasing through e-commerce companies. Second analyzed article (Hwang, Jung, \& Selvendy, 2006) is about exploring e-commerce benefits in developing countries and developing countries are home to more than $80 \%$ of the world's population, and are the site for growing use of e-commerce. In this article authors were focused on e-commerce companies.

Last part of this paper is about possibilities and opportunities for e-commerce implementation in author's country, Kosovo.

Kosovo is relatively new country, and Kosovo had declared independence on 2008. In addition Kosovo was occupied by Serbia from 1912 until 1999 when it was liberated after the war. From 1999 Kosovo was managed by United Nations Mission in Kosovo (UNMIK) and first banks were opened in 2001. Furthermore until year 2004 there was not internet connection for general population. In addition, Kosovo is poorest country in Europe and level of corruption is also highest in Europe. Kosovo is still not recognized by five countries of European Union (Greece, Spain, Slovakia, Cyprus and Romania), and Kosovars are only nation in Europe that need visa to travel within European Union.
\end{abstract}

Keywords:E-commerce, Developing countries, Telecommunication infrastructure

\section{Internationalization of e-commerce}

With implementation of e-commerce, businesses are able to offer their products and services anywhere in the world. In addition, new business concepts had evolved like e-marketing, ebanking and online transaction. According to Hwang, Jung, \&Selvendy (2006) "Web-based ecommerce has provided more opportunities of multinational business to companies, and has enabled consumers to purchase easily what they want from anywhere" (p. 3).

Furthermore through e-commerce implementation, companies can offer products and services for potential consumer that physically don't have access to their retail shops. However, potential customers may have difficulties to conduct online payment because of internet access, trust issues since fraud and hacking may occur during transactions, their personal experience with postal delivery system, high custom rates, legal barriers (for example embargo on specific products and states) and low purchasing power.

In addition, based on literature review (Hwang, Jung, \&Selvendy, 2006; Burtch, Ghose, \&Wattal, 2014; Ha, Noh, \& Choi, 2014) conclusion is that culture is driving force for successful e-commerce implementation. According to Hwang, Jung, \&Selvendy (2006) "The cultural factors involve the compatibility of the Internet and e-commerce with the values and 
norms of a society, and thus influence the degree of acceptance or rejection of the Internet and e-commerce in a society" (p. 4).

Those issues are present in business to consumer (B2C) markets, since B2C market is driven by consumer markets, in which consumers behave according to their shopping preferences and values, whereas business to business (B2B) is related to building the global networks of suppliers, customers and subsidiaries for global competition.

Furthermore, as triggering factor for online consumers are website design for efficient information representation and search, and website design for increasing trust of e-commerce, while cultural, economic and infrastructural factors are playing significant role on diff erences in online shopping preferences among different nations

\section{Exploringe-commercebenefits for businesses ina developing country}

According to Alemayehu\&Heeks (2007) "Developing countries are home to more than $80 \%$ of the world's population, and are the site for growing use of e-commerce" (p. 95) and academic literature suggests that Internet access will enhance e-commerce in developing countries because of greater access to global markets, easier incorporation into global supply chains, cost savings, and disintermediation, however norms, resources, infrastructure, and culture are important that impact on potential online consumers.

Furthermore, E-commerce literature has tended to rely on transaction cost theory and strategic management perspectives (Alemayehu\&Heeks, 2007). Transaction cost refers to the cost of coordination in the production and marketing of a product while according to strategic management perspectives, "businesses that use e-commerce can potentially increase their market reach and at the same time implement mass customization strategies" (Alemayehu\&Heeks, 2007, p.96).

When discussing e-commerce benefits for business in developing countries, three approaches can be discussed, consumer approach, foreign company approach and e-commerce companies that are established in developing country.

Potential consumer in developing country will have opportunity to investigate about price and quality of desired product, however consumer could have trust issues and legal barriers to purchased desired product.

When companies are utilizing e-commerce with the goal to enter in new markets and to gain new consumer, from technological point of view it seems not to be challenging task. However as a result of pre-existing international trade agreements and divided market, legal issues can be raised and recommendation is that existing laws and trade agreements need to be revised and to be updated in correlation with e-commerce.

From utilization of e-commerce in developing countries, domestic companies can benefit from e-commerce technology by offering their services remotely. This can be conducted in the field of information technology server maintenance and in field of configuration and troubleshooting of different hardware and software.

\section{Implementation of e-commerce in Kosovo}

Since 1999, in Kosovo different international organizations where present, like Kosovo Diplomatic Observation Mission in Kosovo (KDOM) United Nations Mission in Kosovo (UNMIK), Kosovo Force in Military (KFOR), Organization for Security and Co-Operation in Europe (OSCE), European Union Rule of Law Mission in Kosovo (EULEX) and those 
organizations had employed more than 10,000 local staff and they are responsible for establishing Kosovo government and civil institutions. In addition, in all those organizations latest information technology was used and local staff was able to attend formal and on job training regarding use of information and communication technology. As a result Kosovo population is already familiar with use of internet and e-commerce as concept could be easily accepted by Kosovars.

However, Kosovo is categorized as developing country and it have some entry barriers that are unique for this category of countries like consumer trust, distribution logistics and legal barriers. According to the law in Kosovo, every online purchase that have value higher than 20 $€$ is subject of $10 \%$ custom and $18 \%$ value added tax (VAT). Furthermore, for every delivery that is arriving through Prishtina Airport, consumers need to pay additional airport terminal fee in value of $15 €$. All those taxes are increasing price of purchased goods and they are having negative impact of e-commerce.

Another issue that could have impact on e-commerce utilization in Kosovo is existing banking system in Kosovo. Currently in Kosovo are operating 11 banks, and banks fees in Kosovo are highest one in the Balkan region. In addition, only one bank in Kosovo (TEB Bank) provides credit card that are accepted for online purchase in USA based companies.

Furthermore in order to open bank account in Procredit Bank in Kosovo, consumer need to make deposit of $500 €$, while in Raiffesien Bank, consumer cannot open bank account if it is not employed. While other banks in Kosovo are charging consumers from $1 \%$ to $3 \%$ of amount that consumers are spending online.

In Kosovo, general population have access on the Internet and in most cities of Kosovo optic fibre network exists. Moreover, internet service providers (ISP) in Kosovo are offering ADSL, XDSL and mobile (4G) internet access for affordable price. Another benefit in Kosovo is that consumers have trust on ISP.

Furthermore, Kosovo government had already started to implement e-governance and Kosovo citizens can used online systems to declare and to calculate taxes, to apply for civil documents and latest e-product that is launched in Kosovo is e-procurement.

\section{Conclusion}

Conclusion is that Kosovo is potential market for e-commerce companies since, market exists, people know how to use internet, purchasing power is acceptable, and however there are high taxes for imported goods and high bank fees for international online transactions.

\section{References}

1. Alemayehu, M., \&Heeks, R. (2007). Exploring E-Commerce benefits for businesses in a developing country. The Information Society, 23, 95-108.

2. Burtch, G., Ghose, A., \&Wattal, S. (2014). Cultural differences and geography as determinants of online prosocial lending. MIS Quarterly, 38(3), 773-794.

3. Ha, S., Noh, M., \& Choi, S. (2014). Difference in the adoption of internet open markets between transition and established market economies. Electronic Commerce Research, 14(4), 531-558.

4. Hwang, W., Jung, H. S., \&Selvendy, G. (2006). Internationalisation of e-commerce: a comparison of online shopping preferences among Korean, Turkish and US populations. Behaviour\& Information Technology, 25(1), 3-18.

5. SMC. (2017). Lecture Notes. SMC University. 